\title{
Indigenous Peoples' Rights and the Norwegian Courts Moving into 2021
}

\author{
Øyvind Ravna \\ UiT The Arctic University of Norway
}

Welcome to 2021 and Volume 12 of the Arctic Review. Over the past year, despite the fact that the world has been shut down due to Covid-19, we managed to gather a significant number of well-qualified researchers to write thirteen excellent and original articles to celebrate ten years of the Arctic Review. These articles were published in an anniversary anthology, which is also available in a limited hardcover edition entitled Ten Years of Law and Politics from an Arctic Perspective. For those who have still not acquired the book, it is available from the publisher Cappelen Damm, as well as academic bookstores. Previous to the anthology, we published three other original articles, bringing the volume close to the peak year of 2018, when we published eighteen original articles. I am grateful to the editorial team, the reviewers and particularly to Nigel Bankes and Katia Stieglitz for their great effort and editorial work. I would also like to thank all those who have submitted well-written and wellresearched manuscripts over the past year.

At the outset of this new year, I would like to use the opportunity to focus on the legal protection of indigenous peoples' culture and land rights in the Norwegian courts of law. In recent years, the Norwegian Supreme Court has handed down judgments that have provoked reactions in the Sámi communities, as they have neither been perceived as well rooted in law and facts, nor in Sámi culture and legal understanding. Furthermore, these judgments have not been perceived as just and fair. This has contributed to a weakening of the much-needed legitimacy of the courts in the Sámi communities. It has also led to reactions at the Sámi political level. On several occasions Sámi President Aili Keskitalo (NSR) has criticized the Norwegian Supreme Court for a lack of cultural competence and thus the ability to safeguard the legal security of the Sámi.

The Jovsset Ante Sara ruling (HR-2017-2428-A), in which the Supreme Court upheld the administration's decision that a young reindeer owner had to slaughter his herd, was a significant contributor to the first such statement by President 
Keskitalo in her New Year's speech at the beginning of 2018. The case is now to be assessed by the UN Human Rights Committee, which hopefully will look at the issues from a more nuanced cultural and human rights perspective than the Supreme Court. The Nesseby case (HR-2018-456-P), in which a local community association in a Sámi area was denied the right to govern and control their hunting and fishing rights, although the rights in themselves were not disputed, is another case that has attracted attention. The reason for this, among other things, is the questionable nature of the historical facts upon which the Supreme Court based its decision. In addition, the court placed little emphasis on assessing Sámi culture and use of nature, which the same court had pointed out the necessity of in the Selbu verdict seventeen years earlier.

Reference can also be made to several cases from the courts of appeal, including the case of the Swedish Saarivuoma Sámi village grazing rights in Norway (LH-2019-68920) and the case of the legality of wind power development in Sámi reindeer pastures at Fosen in Trøndelag (LF-2018-150314 et al.). Both rulings have been to the detriment of the Sámi. These cases contrast with the Girjas judgment (T 853-18) in neighboring Sweden, where the Swedish Supreme Court used international customary law to justify that Girjas Sámi village has the right to manage hunting and fishing in the Sámi village's resource area.

In November 2020, the Sámi Parliamentary Council had had enough, announcing that it would promote a plenary case in the Sámi Parliament on the Sámi's legal security during the spring of 2021. "There is no doubt that there is a difference between the Sámi's rights on paper, and the rights that are actually fulfilled," said President Keskitalo on this occasion. A few days later, Vesterålen District Court concluded that a reindeer husbandry group did not have grazing rights within the Sámi reindeer husbandry area on Hinnøya in Nordland (20-070459TVI-VTRA), which has hardly helped to re-establish trust.

In early January 2021, the Norwegian Supreme Court announced that it will hear the aforementioned wind power case from Fosen in a grand chamber. The case primarily concerns the legality of the state authorization decision and the expropriation permit for the construction of a huge wind power plant on the Fosen Peninsula. The decision entails a significant intervention in core areas for South Sámi reindeer husbandry, where the facility was built before the legality of the endeavor was fully tried by the courts.

As mentioned above, the Frostating Court of Appeal had previously confirmed that the authorization and expropriation were valid. Thus, reindeer husbandry lost the claim to remove the wind power plants from the grazing areas. The question that will now be decided by the Supreme Court, is whether the intervention in reindeer husbandry rights is legal, both according to Norwegian national law and according to international law obligations Norway is bound by. A question that will be tried is how far the obligation to consult extends, and whether this obligation, in extensive interventions such as this, requires that representative Sámi institutions 
give their free, prior and informed consent before such a decision is made and realized.

It is positive that the Supreme Court will hear the Fosen case in its Grand Chamber. It is expected that the Grand Chamber will hold up the huge intervention that has taken place, against Norway's obligations under international law in an objective manner. In this way the South Sámi can receive a just and fair treatment of their demand to remove the wind power plant from their reindeer pastures. It is also expected that the Supreme Court will show integrity in relation to state power and emphasize that representatives of the South Sámi herders had not given their free, prior and informed consent to the development.

In addition to raising concerns about the Norwegian courts' safeguarding of indigenous peoples' rights, the Arctic Review has the pleasure of being able to present two original, peer-reviewed articles at the beginning of 2021. In "Ten years of international shipping on the Northern Sea Route", Björn Gunnarsson, Nord University, and Arild Moe, Fridtjof Nansen Institute, discuss voyages on the Northern Sea Route (NSR) along the northern coast of Russia since international use began in 2010. They show that there has been strong growth in destination shipping between the Arctic and ports outside the region, but transit shipping between the Pacific and the Atlantic has not experienced the growth many had anticipated. The reasons for this development are analyzed in the article.

In "The Arctic and Africa in China's foreign policy", Christer Pursiainen, UiT The Arctic University of Norway, Chris Alden, London School of Economics, and Rasmus Bertelsen, UiT The Arctic University of Norway, analyze the differences in these two political approaches. By studying China's policies towards the Arctic and Africa from a comparative perspective, the authors conclude that China's regional strategies suitably reflect the overall grand strategy of a country that is slowly but surely aiming at taking on the role of leading global superpower.

For 2021 I hope the Arctic Review will receive many topical manuscripts, not only about indigenous peoples and the protection of their rights in the courts, but also more generally on topics from the fields of law and social sciences related to the Circumpolar Northern societies and the High North. In this way the journal will be able to continue to publish plenty of excellent research articles. A Happy New Year to all of our readers and Arctic researchers! 